\title{
Changes in fetal fluid composition during the last 60 days of gestation in goats
}

\author{
R. Anne Pearson* and D. J. Mellor \\ Moredun Research Institute, Gilmerton, Edinburgh, EHI7 7JH, U.K.
}

\begin{abstract}
Although the fetal fluids of sheep have been examined in detail in conscious catheterized animals after about 60 days of pregnancy (Mellor \& Slater, 1971, 1972, 1973a; Mellor \& Matheson, 1977) there is no comparable information for goats. We have therefore examined the composition of the fetal fluids from conscious goats for comparison with the sheep data.

Twenty-five pregnant British Toggenburg $\times$ mixed breed goats $(40-80 \mathrm{~kg})$ at known stages of pregnancy were used; 15 carried twins, 9 had single fetuses and 1 triplets. The animals were penned individually and received $0.8-1.0 \mathrm{~kg}$ pelleted feed (Ruminant A: Seafield Mill, Midlothian) and 0.3$0.5 \mathrm{~kg}$ hay per day. They were handled daily, including sampling from a jugular vein, for 4 weeks and were fasted for $48 \mathrm{~h}$ before operation. Between 81 and 111 days of gestation catheters were inserted into the allantoic and/or amniotic sacs of 36 fetuses (Mellor, 1970a) and into the bladders of 3 of them (Mellor, Williams \& Matheson, 1972). Fetal fluids, fetal urine and maternal plasma were sampled daily (Mellor et al., 1972) before feeding at 09.30-10.30 h, until term or abortion. Eleven goats (Group A) received no progesterone, 10 (Group B) were given $20 \mathrm{mg}$ progesterone (Organon Laboratories Ltd., Surrey) i.m. in oil once daily from the day before until 3-5 days after operation, the dose then being decreased progressively to zero during the next 2-4 days, and 4 goats (Group C) were given 10$15 \mathrm{mg}$ progesterone/day from the day of operation until term. All analytical procedures were as described by Mellor \& Slater (1973b), apart from those for fructose (Roe, 1934) and calcium and magnesium (Mellor \& Matheson, 1977). Progesterone concentrations were measured using a modified competitive protein-binding assay based on those described by Thorburn, Bassett \& Smith (1969) and Challis, Heap \& Illingworth (1971). The extraction effciency was $89 \pm 1 \cdot 3 \%$ (S.E.M.) $(n=14)$, the values for distilled water blanks were always $<0.2 \mathrm{ng} / \mathrm{ml}$, and the interassay coefficient of variation was $20 \%$.
\end{abstract}

Abortion occurred 2-3 days after surgery in 4 of 11 goats in Group A, after 8-13 days in 6 of 10 goats in Group $B$ and in none of the 4 goats in Group C. During the last 2 days before abortion the mean $( \pm$ S.D.) plasma progesterone concentration decreased from $7.6 \pm 4 \cdot 2$ to $0.8 \pm 0.5 \mathrm{ng} / \mathrm{ml}$ $(\mathrm{N}=10)$, and this decrease started within $24 \mathrm{~h}$ of surgery in the Group A animals. All aborted fetuses were alive at delivery, and the likely cause of abortion was therefore lutolysis induced by the stress of surgery. Although short-term progesterone treatment appeared to delay abortion in Group B, the frequencies of abortion in Groups $A$ and $B$ were not significantly different $\left(\chi^{2}\right.$ test). Of the remaining 15 animals, the pregnancies of 3 were terminated 3-4 weeks after operation because of persistent sampling difficulties, and 12 (including all 4 from Group C) carried their fetuses to full term (148-155 days) and gave birth spontaneously. The $18 \mathrm{kids}$ of which 13 were catheterized, had birthweights of 2.2$3.3 \mathrm{~kg}$ and growth rates during the first 5 weeks of $0.9-1 \cdot 1 \mathrm{~kg} /$ week.

Postoperative changes in amniotic fluid and in allantoic fluid were qualitatively similar in each fetus whether abortion occurred or not, and were similar to those reported for sheep (Mellor \& Slater, 1971, 1973a; Mellor \& Matheson, 1977). In the animals which did not abort the time required for the establishment of stability or of subsequently observed gestational trends varied according to the substance being considered, but was never more than 10 days in any goat. It took up to 12 days for maternal plasma composition to stabilize, and thereafter the concentrations of all substances remained relatively constant (see Table 1).

During the last 70 days of pregnancy changes in the composition of amniotic fluid were qualitatively similar in 6 fetuses carried by 5 goats in Groups A and B (Table 1). Few samples were obtained

* Present address: A.R.C. Poultry Research Centre, West Mains Road, Edinburgh, U.K. 
Table 1. Ten-day interval means for the osmolality and the concentration of sodium, potassium, chloride, fructose, urea, calcium and magnesium in amniotic fluid from 6 goat fetuses after post-operative stabilization

\begin{tabular}{|c|c|c|c|c|c|c|c|c|c|c|}
\hline $\begin{array}{l}\text { Gestational } \\
\text { age (days) }\end{array}$ & $\begin{array}{c}\text { No. of } \\
\text { observations }\end{array}$ & $\begin{array}{l}\text { No. of } \\
\text { fetuses }\end{array}$ & $\begin{array}{l}\text { Osmolality } \\
\text { (mosmol/ } \\
\text { kg water) }\end{array}$ & $\begin{array}{l}\mathrm{Na} \\
(\mathrm{mM})\end{array}$ & $\underset{(\mathrm{mM})}{\mathbf{K}}$ & $\begin{array}{c}\mathrm{Cl} \\
(\mathrm{mM})\end{array}$ & $\begin{array}{l}\text { Fructose } \\
\text { (mM) }\end{array}$ & $\begin{array}{l}\text { Urea } \\
\text { (mM) }\end{array}$ & $\begin{array}{l}\mathrm{Ca} \\
(\mathrm{mM})\end{array}$ & $\begin{array}{l}\mathrm{Mg} \\
(\mathrm{mM})\end{array}$ \\
\hline \multicolumn{11}{|l|}{ Amniotic fluid } \\
\hline $81-90$ & $2-14$ & 3 & - & 129 & $5 \cdot 1$ & 123 & $8 \cdot 4$ & - & 3.08 & 0.46 \\
\hline $91-100$ & $21-53$ & 6 & 300 & 129 & $5 \cdot 4$ & 124 & $11 \cdot 1$ & $2 \cdot 70$ & 2.93 & 0.58 \\
\hline $101-110$ & $31-45$ & 6 & 310 & 120 & $7 \cdot 0$ & 121 & $18 \cdot 1$ & $2 \cdot 63$ & 3.05 & 0.71 \\
\hline $111-120$ & $21-49$ & 6 & 313 & 111 & 8.9 & 117 & $15 \cdot 6$ & $4 \cdot 23$ & $2 \cdot 80$ & 1.04 \\
\hline $121-130$ & $23-35$ & 6 & 327 & 107 & $9 \cdot 2$ & 113 & $14 \cdot 2$ & $5 \cdot 62$ & $2 \cdot 36$ & 1.46 \\
\hline $131-140$ & $12-22$ & 3 & 309 & 97 & $15 \cdot 3$ & 112 & $12 \cdot 3$ & 5.92 & 1.85 & $1 \cdot 42$ \\
\hline $141-150$ & $6-9$ & 2 & 292 & 91 & 23.8 & 103 & $12 \cdot 2$ & $9 \cdot 20$ & 1.83 & 1.58 \\
\hline Average S.D. & & & 29 & 6.08 & 1.37 & 6.78 & $4 \cdot 22$ & 0.90 & 0.79 & 0.42 \\
\hline \multicolumn{11}{|l|}{ Maternal plasma } \\
\hline $81-150$ & $125-281$ & 5 & 280 & 139 & 3.98 & 112 & N.D. & $2 \cdot 60$ & $2 \cdot 83$ & $1 \cdot 13$ \\
\hline & & S.D. & 10 & $4 \cdot 7$ & 0.34 & $6 \cdot 2$ & & 0.65 & 0.48 & 0.24 \\
\hline
\end{tabular}

N.D., not detectable.

after 140 days of gestation because the fluid became increasingly gelatinous and blocked most catheters.

Allantoic fluid was sampled for 20-45 days in 7 single fetuses, including the 4 from Group C. Few samples were obtained after 135 days. The osmolality showed a general tendency to increase during the sampling period (mean $330 \pm 32(n=110) \mathrm{mosmol} / \mathrm{kg}$ water). Within each fetus there was a significant negative correlation between the sodium (10-120 mM) and potassium (20-90 mM) concentrations of allantoic fluid $(r=-0.50$ to $-0.98, n=21-42)$. Chloride concentrations were 20$45 \mathrm{~mm}$ until about 118 days of gestation when they increased continuously to reach a maximum of $87 \pm$ $7(n=7) \mathrm{mm}$ between 125 and 135 days. The fiuid fructose concentrations showed linear decreases in each fetus, the highest values being $10 \cdot 0-36 \cdot 1 \mathrm{~mm}$ and the lowest $5 \cdot 0-18 \cdot 9 \mathrm{~mm}$. The urea $(3 \cdot 34-6 \cdot 34$ $\mathrm{mm}$ ) and magnesium (3.42-4.33 $\mathrm{mm})$ concentrations remained relatively constant, but calcium concentrations decreased from $13 \cdot 0-40 \cdot 0 \mathrm{~mm}$ within 3 days of operation to $2 \cdot 50-11 \cdot 3 \mathrm{~mm}$ after 20 45 days.

Daily samples of fetal urine were obtained from 3 fetuses until abortion 8,9 and 13 days after operation. The results for each parameter between the 1 st and 7 th day after operation were pooled and gave mean \pm S.D. (n) values of $347 \pm 102(20)$ mosmol $/ \mathrm{kg}$ water, $59 \pm 11 \mathrm{~mm}$-sodium (21), $6.9 \pm 2.3$ mM-potassium (21), $43 \pm 12$ mM-chloride (21), $14 \cdot 3 \pm 9 \cdot 4$ mM-fructose (21) and 9.67 $\pm 4 \cdot 17$ mM-urea (21). Although the operation probably affected these values they have been included because they are the only data available.

\section{Discussion}

During the last 60 days of pregnancy the changes in the composition of amniotic fluid in the goats in the present study (Table 1) and the sheep examined by Mellor \& Slater $(1971,1973 a)$ were almost identical. Because the relative compositions of fetal urine and amniotic fluid in both species were also similar, it may be argued that, in the goat, as in the sheep, fetal urine flows at increasing rates into the amniotic sac after 80-90 days of gestation. Such a flow would account for the high osmolality and the changes in the sodium, potassium and urea concentrations of amniotic fluid, but would need to be combined with decreasing fructose concentrations in fetal urine to account for the decrease in the fluid fructose concentrations after $\mathbf{1 1 0}$ days of gestation.

In the sheep, it has been suggested that chloride ions are actively transported from fetal plasma into amniotic fluid until about 130-135 days of gestation, after which chloride pumping apparently decreases (Mellor, 1970b; Mellor \& Slater, 1971). Because the electrochemical gradients between fetal plasma and amniotic fluid (Mellor, 1970b) and the gestational trends in the fluid chloride concentrations (Mellor \& Slater, 1971) are similar in goats and sheep, a similar pattern of chloride pumping 
presumably occurs in the goat. As in the sheep (Mellor \& Matheson, 1977), the calcium and magnesium concentrations of amniotic fluid would be determined largely by a balance between their diffusion into the amniotic sac down the electrochemical gradient generated by chloride pumping and effects of the entry of fetal urine into the amniotic sac.

Changes in the composition of goat allantoic fluid (present study) were also similar to those observed in sheep (Mellor \& Slater, 1971, 1973a; Mellor \& Matheson, 1977). However, although there. were negative correlations between the fluid sodium and potassium concentrations in both species;. the changes in the goats with gestation were markedly different from those in sheep (Mellor \& Slater, $1971,1972)$. Higher chloride concentrations $(60-90 \mathrm{~mm})$ were found in allantoic fluid from conscious goats than were normally present in fluid from conscious sheep (usually $<50 \mathrm{~mm}$, Mellor \& Slater, 1971) or anaesthetized goats (Mellor, 1970b), and the rise in chloride concentration to these levels coincided with an increase in the sodium and a decrease in the potassium concentrations of the fluid. Mellor (1970b) has suggested that relatively low chloride concentrations in allantoic fluid are maintained passively by the electrochemical gradients between maternal and fetal plasma and allantoic fluid, and that these gradients are generated by sodium and possibly potassium pumps in the chorioallantoic membrane. The unusual electrolytechanges after 118 days in fluid from the present animals could therefore have resulted from an increase in the permeability of the chorioallantois to these ions, or to a decrease in sodium pumping activity, or both. Since these electrolyte changes occurred in the fluid from all 7 goats, the daily progesterone injections in the 4 Group-C animals are not likely to have been involved. Indeed, the general compositions of allantoic fluid from the animals in the three treatment groups were indistinguishable.

We conclude that the factors which regulate or alter the compositions of the fetal fluids, particularly the amniotic fluid, of sheep and goats during the last half of pregnancy are probably similar.

We are grateful to all who assisted, particularly MrW. R. Carr, Dr A. C. Field, Mr I. C. Matheson, Mr M. McLauchlan, Dr M. Phillippo, and Mr A. Wilson.

\section{References}

Challis, J.R.G., Heap, R.B. \& Illingworth, D.V. (1971) Concentrations of oestrogen and progesterone in the plasma of non-pregnant, pregnant and lactating guinea-pigs. J. Endocr. 51, 333-345.

Mellor, D.J. (1970a) A technique for chronic catheterisation of the amniotic and allantoic sacs of sheep foetuses. Res. vet. Sci. 11, 93-95.

MelLoR, D.J. (1970b) Distribution of ions and electrical potential differences between mother and foetus at different gestational ages in goats and sheep. J. Physiol., Lond. 207, 133-150.

Mellor, D.J. \& Matheson, I.C. (1977) Variations in the distribution of calcium, magnesium and inorganic phosphorus within chronically catheterized sheep conceptuses during the last eight weeks of pregnancy. Q. Jl exp. Physiol. 62, 55-63.

Mellor, D.J. \& Slater, J.S. (1971) Daily changes in amniotic and allantoic fluid during the last three months of pregnancy in conscious unstressed ewes, with catheters in their foetal fluid sacs. J. Physiol., Lond. 217, 573-604.

MelloR, D.J. \& SlAter, J.S. (1972) Daily changes in foetal urine and relationships with amniotic and allantoic fluid and maternal plasma during the last two months of pregnancy in conscious unstressed ewes with chronically implanted catheters. $J$. Physiol., Lond. 227, 503-525.

MelloR, D.J. \& Slater, J.S. (1973a) Variations in the distribution of glucose and fructose within chronically catheterised sheep conceptuses during the last two months of pregnancy. Res. vet. Sci. 15, 317-321.

MelloR, D.J. \& Slater, J.S. (1973b) The composition of maternal plasma and foetal urine after feeding and drinking in chronically catheterised ewes during the last two months of pregnancy. J. Physiol., Lond. 234, 519-531.

Mellor, D.J., Williams, J.T. \& Matheson, I.C. (1972) A technique for chronic catheterisation of the bladder of the foetal sheep. Res. vet. Sci. 13, 87-88.

RoE, J.H. (1934) A colorimetric method for the determination of fructose in blood and urine. J. biol. Chem. 107, 15-22.

ThorburN, G.D., BasseTr, J.M. \& SMiTh, I.D. (1969) Progesterone concentration in the peripheral plasma of sheep during the oestrous cycle. J. Endocr. 45, 459-469. 